\title{
Effects of Periodic Manual Stirring and Uranium Addition on Surrogate Plutonium Glass Processing (U)
}

by

T. F. Meaker

Westinghouse Savannah River Company

Savannah River Site

Aiken, South Carolina 29808



DOE Contract No. DE-AC09-89SR 18035

This paper was prepared in connection with work done under the above contract number with the U.S. Department of Energy. By acceptance of this paper, the publisher and/or recipient acknowledges the U.S. Government's right to retain a nonexclusive, royalty-free license in and to any copyright covering this paper, along with the right to reproduce and to authorize others to reproduce all or part of the copyrighted paper. 


\section{DISCLAIMER}

This report was prepared as an account of work sponsored by an agency of the United States Government. Neither the United States Government nor any agency thereof, nor any of their employees, makes any warranty, express or implied, or assumes any legal liability or responsibility for the accuracy, completeness, or usefulness of any information, apparatus, product, or process disclosed, or represents that its use would not infringe privately owned rights. Reference herein to any specific commercial product, process, or service by trade name, trademark, manufacturer, or otherwise does not necessarily constitute or imply its endorsement, recommendation, or favoring by the United States Government or any agency thereof. The views and opinions of authors expressed herein do not necessarily state or reflect those of the United States Government or any agency thereof.

This report has been reproduced directly from the best available copy.

Available to DOE and DOE contractors from the Office of Scientific and Technical

Information, P. O. Box 62, Oak Ridge, TN 37831; prices available from (423) 576-8401.

Available to the public from the National Technical Information Service. U. S. Department of Commerce, 5285 Port Royal Rd., Springfield, VA 22161 


\section{DISCLAMMER}

Portions of this document may be illegible in electronic image products. Images are produced from the best available original document. 


\section{WESTINGHOUSE SAVANNAH RIVER COMPANY}

SAVANNAH RIVER TECHNOLOGY CENTER

SRT-TR-96-0321 Rev. 0

Keywords: Plutonium surrogate, stirred melt, uranium addition, residence time.

September 13, 1996

To: Distribution, 773-A

From: T.F. Meaker, 773-A TFW

Effects of Periodic Manual Stirring and Uranium Addition on Surrogate Plutonium Glass Processing

CC: E.W. HOLTZSCHEITER, 773-A

J.M. PAREIZS, 773-A

N.E. BIBLER, 773-A

D.K. PEELER, 773-A

J.C. MARRA, 773-43A

M.J. PLODINEC, 773-A

E.F. DUHN, 773-A

D.A. CROWLEY, 773-43A

T.Y. BAXTER, 773-A

STI (4) 


\section{Summary}

Using thorium as a plutonium surrogate, homogeneous glasses have been processed ranging from 15 to 20 elemental weight percent thorium with 0 to 5 elemental weight percent uranium. Homogeneous glasses have been processed at $1475^{\circ} \mathrm{C}$ with residence times ranging from 1 to 12 hours. High ramp rates successfully inhibited thorium silicate formation. Residence times of 5 to 7 hours were required for static melts to become homogeneous for glasses containing 15 elemental weight percent thorium. Thorium dissolution rates have been determined for glasses containing 15 elemental weight percent thorium with and without the addition of uranium. When compared to identical glass compositions which were not stirred, stirred melts produced homogeneous vitreous products with an 80 percent reduction in residence time. A 20 elemental weight percent thorium glass was produced at $1475^{\circ} \mathrm{C}$ by adding 2 elemental weight percent uranium. Without the addition of uranium, a melt temperature of $1500^{\circ} \mathrm{C}$ was required.

\section{Introduction}

In support of the plutonium immobilization program at the Savannah River Site (SRS), lanthanide borosilicate (LaBS) glass compositions are being studied for plutonium vitrification. The glass composition used in this study is based on the glass composition developed for the Am/Cm Demonstration Project at SRS[1].Tests to determine the dissolution rate and solubility limits of plutonium that can be dissolved into the glass have been determined for static and stirred melts. Static melts were performed to provide a worst case scenario with respect to dissolution kinetics. Static conditions simulate a glass processing scheme with very little natural convection within the glass/melt pool. Melts that are periodically stirred were performed to more accurately reflect actual melting conditions (i.e. convection currents). Although, it is not known how closely manual stirring corresponds to actual convection currents, it is believed that residence times can be reduced (which, in turn, reduce processing times) when natural convection currents are considered. In this preliminary study, dissolution rates for thorium (a plutonium surrogate) loaded glasses have been determined for static and manually stirred melts. These initial tests used thorium as a plutonium surrogate to gain insight that will be used for future plutonium melts. Thorium was used as a surrogate based on a comparison of thorium oxide and plutonium oxide with respect to density[2] and crystal structure of oxide[2], and valence state ${ }^{\dagger}$ in the high temperature LaBS glass. These predictions will be tested on a smaller scale (fewer melts) with actual Pu glass melts (static and stirred) performed in a glove box. The concentration of uranium present in potential plutonium feeds raises solubility and processing questions. For example, will the actual plutonium loading need to be lowered to account for the presence of uranium? Will residence times required for a homogeneous glass need to be adjusted compared to plutonium only glasses?

\section{Experimental}

\section{Glass Production and Processing}

Glasses were batched with reagent chemicals in the oxide or silicate form except for thorium nitrate, neodymium nitrate and boric acid. Dry chemicals were added to a $100 \mathrm{~mL}$ platinum crucible and thoroughly mixed. The processing temperature was $1475^{\circ} \mathrm{C}$. By using predominately oxides and silicates in the batch, a high ramp rate (560 C/hour) could be used without violent gas evolution resulting in loss of product. Static melts were not stirred and had residence times ranging from 10 minutes to 16 hours. Agitated (manually

$\uparrow$ Telephone conversation with John Vienna, Pacific Northwest National Laboratory (PNNL). 
stirred) melts were stirred every 1 to 4 hours. The residual material on the stir bar after each stir was analyzed by X-Ray Diffraction (XRD) for insoluble material. Various residence times were evaluated on individual melts to determine the time of complete dissolution. Table I and II show the batched compositions in mole percent oxide for all glasses in this study.

\begin{tabular}{|c|c|c|c|c|}
\hline $\begin{array}{c}\text { Table I. Th } \\
\text { Oxide }\end{array}$ & $\begin{array}{l}\text { ranium } \\
10 \mathrm{Th} \\
\end{array}$ & $\begin{array}{c}\text { ompo } \\
15 \mathrm{Th}\end{array}$ & $\begin{array}{l}\text { perce } \\
115 \mathrm{U} \\
\end{array}$ & $\underline{20 T h}$ \\
\hline $\mathrm{SiO} 2$ & 42.6 & 42.6 & 42.6 & 42.6 \\
\hline $\mathrm{B} 2 \mathrm{O} 3$ & 12.0 & 12.0 & 12.0 & 12.0 \\
\hline $\mathrm{Al} 2 \mathrm{O} 3$ & 24.0 & 24.0 & 24.0 & 24.0 \\
\hline $\mathrm{ZrO} 2$ & 1.0 & 1.0 & 1.0 & 1.0 \\
\hline $\mathrm{BaO}$ & 1.5 & 1.5 & 1.5 & 1.5 \\
\hline $\mathrm{PbO}$ & 4.2 & 4.2 & 4.2 & $-4: 2$ \\
\hline $\mathrm{La} 2 \mathrm{O} 3$ & 6.1 & 2.4 & 2.6 & $=0.9$ \\
\hline $\mathrm{Nd} 2 \mathrm{O} 3$ & 1.0 & 1.0 & 1.0 & $1.0^{-}$ \\
\hline $\mathrm{Gd} 2 \mathrm{O} 3$ & 2.5 & 3.8 & 3.7 & 2.9 \\
\hline UO3 & -- & -... & 7.4 & -.. \\
\hline ThO2 & 5.1 & 7.5 & $\cdots$ & 9.9 \\
\hline
\end{tabular}

Table II. Mole percent oxide compositional range of Pu surrogate glasses processed.

\begin{tabular}{|c|c|c|c|c|c|c|}
\hline Oxide & $2 \mathrm{U} 15 \mathrm{Th}$ & 5 U10Th & 5U15Th & 2U18Th & 10U5Th & $2 \mathrm{U} 20 \mathrm{Th}$ \\
\hline $\mathrm{SiO} 2$ & 42.6 & 42.6 & 42.6 & 42.6 & 42.6 & 42.6 \\
\hline $\mathrm{B} 2 \mathrm{O} 3$ & 12.0 & 12.0 & 12.0 & 12.0 & 12.0 & 12.0 \\
\hline $\mathrm{Al} 2 \mathrm{O} 3$ & 24.0 & 24.0 & 24.0 & 24.0 & 24.0 & 24.0 \\
\hline $\mathrm{ZrO} 2$ & 1.0 & 1.0 & 1.0 & 1.0 & 1.0 & 1.0 \\
\hline $\mathrm{BaO}$ & 1.5 & 1.5 & 1.5 & 1.5 & 1.5 & 1.5 \\
\hline $\mathrm{PbO}$ & 4.2 & 4.2 & 4.2 & 4.2 & 4.2 & 4.2 \\
\hline $\mathrm{La} 2 \mathrm{O} 3$ & 1.4 & 2.5 & 0.0 & 0.0 & 2.5 & 0.3 \\
\hline $\mathrm{Nd} 2 \mathrm{O} 3$ & 1.0 & 1.0 & 1.0 & 0.4 & 1.0 & 0.4 \\
\hline $\mathrm{Gd} 2 \mathrm{O} 3$ & 3.8 & 3.7 & 3.8 & 4.4 & 3.8 & 3.2 \\
\hline UO3 & 1.0 & 2.5 & 2.4 & 1.0 & 4.9 & 1.0 \\
\hline ThO2 & 7.5 & 5.0 & 7.5 & 8.9 & 2.5 & 9.8 \\
\hline
\end{tabular}

The platinum crucibles, containing the melts, were removed from the furnace and placed in an inch of water in a stainless steel pan. The crucible was covered to avoid loss of product due to shattering. This caused the glass to be 'shocked' from the crucible surface allowing easy recovery of the entire glass sample. Table III shows the different glasses processed, the targeted actinide loading, stir times, residence times of each melt and the minimum time the melt required to become homogeneous. All melts targeted 50 grams of glass except were noted.

XRD and Weight Percent Crystal Analysis

Homogeneity was determined by X-ray diffraction (XRD) of the residual glass adhered to the stir bar after stirring. A standard X-ray diffraction pattern was obtained on this material. Approximately 0.1 grams of glass was ground to a powder for the analysis. 
Weight percent crystal determinations were performed by grinding the entire 50 gram sample in a SPEX 8000 mill and mixer. A partial spectrum targeting the major uranium and thorium peaks was performed on a 0.1 gram sample from the entire glass sample. The peak height of the sample was compared to the peak height of standards to determine the weight percent crystals in the glass sample. Standards were prepared by combining thorium or a thorium/uranium solid solution with aluminum oxide in varying concentrations. The uranium/thorium oxide solid solution was prepared using the same ratio of uranium to thorium oxides (only) as batched in the glass and heated to $1475^{\circ} \mathrm{C}$.

\section{Results and Discussion}

A series of glasses targeting 15 elemental weight percent Th were processed. These glasses (15Th - static) were melted without stirring (static) with residence times ranging from 10 minutes to 8 hours. The static melts were homogeneous after 5 hours at $1475^{\circ} \mathrm{C}$. After 10 minutes, 95.3 percent (based on quantitative XRD) of all thorium had dissolved into the glass. After 20 minutes, 97.1 percent had dissolved into the glass. After 30 minutes, approximately 98 percent of all the thorium had dissolved into the glass. This level was maintained throughout the first four hours at temperature. Complete dissolution occured after 5 hours.

Several glasses with the same composition (15 elemental weight percent thorium) were processed with stirring 30 minutes after reaching the processing temperature $(15 \mathrm{Th}-1$ stir). Stirring the melt was done to conservatively simulate the natural convection currents inside of a melter. Glasses that were stirred once were homogeneous after one hour at temperature. This represents an 80 percent reduction in residence time as compared to the couterpart static melts.

Another set of 15 elemental weight percent thorium glasses were stirred twice, once after 30 minutes at temperature and again after 90 minutes at temperature. These glasses were homogeneous with the second stirring. Figure 1 shows the percent of all thorium dissolved into the glass with respect to time of the static and stirred melts.

A similar set of static melts were processed with 15 elemental weight percent thorium and 2 elemental weight percent uranium $2 \mathrm{U} 15 \mathrm{Th}$. As seen in figure 1, adding uranium resulted in slower kinetics with respect to thorium dissolution. However, a homogeneous product was reached after 8 hours at $1475^{\circ} \mathrm{C}$.

Thorough mixing of chemicals is essential for homogeneous glass production. This became evident while processing the 30 gram glasses $(15 \mathrm{Th}$-static/30g) without stirring or proper mixing. These glasses were never completely homogeneous, even after 16 hours of residence time. A small $\mathrm{ThO} 2$ layer remained on the bottom of the melt pool. One 100 gram melt was processed for 7 hours without stirring (15Th - static/100g). Steps were taken to ensure the batch was well mixed. This glass was homogeneous, indicating that with proper mixing, scaling up should not pose a problem.

The use of high ramp rates successfully inhibited the formation of thorium silicate, often present on the bottom of the crucible during previous processing attempts using nitrates with low ramp rates. The formation of thorium silicate was found to drastically increase the residence time needed to produce a homogeneous product. XRD patterns of nonhomogeneous samples in this study of "thorium only" glasses found undissolved thorium oxide present on the bottom of the crucible. Non-homogeneous samples of "uranium/thorium" glasses contained a solid solution of uranium oxide and thorium oxide on the bottom of the crucible. 
Table III. Thorium and/or uranium glasses processed with actinide loading, stir times and residence times listed.

\begin{tabular}{|c|c|c|c|c|}
\hline Glass ID & $\frac{\text { Act. Loading }}{\text { (elem. wt \%) }}$ & $\frac{\text { Stir Times }}{\left.\text { (hrs at } 1475^{\circ} \mathrm{C}\right)}$ & $\frac{\text { Residence Time }}{\text { Attempted }}$ & $\frac{\text { Homogeneous }}{\left.\text { (hrs at } 1475^{\circ} \mathrm{C}\right)}$ \\
\hline 10Th-static & 10 Thorium & None & 7.5 & 7.5 \\
\hline $15 \mathrm{Th}$ & 15 Thorium & $0.5,1,3,6$ & 7.5 & 1 \\
\hline $15 U$ & 15 Uranium & $1,3,6$ & 7.5 & 7.5 \\
\hline $1005 \mathrm{Th}$ & $10 \mathrm{U} \& 5 \mathrm{Th}$ & $1,3,6$ & 7.5 & 3 \\
\hline $5 \mathrm{U} 10 \mathrm{Th}$ & $5 \mathrm{U} \& 10 \mathrm{Th}$ & $1,3,6$ & 7.5 & 3 \\
\hline $5 \mathrm{U} 15 \mathrm{Th}$ & $5 \mathrm{U} \& 15 \mathrm{Th}$ & $4,6,8,11$ & 12 & 11 \\
\hline 2U18Th & $2 \mathrm{U} \& 18 \mathrm{Th}$ & $4,6,8,11$ & 12 & 11 \\
\hline 2U15Th-static & $2 \mathrm{U} \& 15 \mathrm{Th}$ & None & $.5,1,2,4,5,6,7,8$ & $\therefore 8$ \\
\hline 15Th-static & 15 Thorium & None & $\begin{array}{c}1 / 6,1 / 3,1 / 2,1,2 \\
4,5,6,7,8\end{array}$ & $\therefore-5$ \\
\hline 15Th (2 stirs) & 15 Thorium & $0.5,1.5$ & 2,4 & 2 \\
\hline $15 \mathrm{Th}$ (1 stir) & 15 Thorium & 0.5 & $1,2,4$ & $\overline{1}$ \\
\hline $\begin{array}{l}15 \text { Th-static } \\
30 \mathrm{~g}\end{array}$ & 15 Thorium & None & $4,8,12,16$ & None $b$ \\
\hline $15 \mathrm{Th}-100 \mathrm{~g}$ & 15 Thorium & 1,5 & 7 & 5 \\
\hline $\begin{array}{l}15 \mathrm{Th} \text {-static } \\
100 \mathrm{~g}\end{array}$ & 15 Thorium & None & 7 & 7 \\
\hline $20 \mathrm{Th}$ & 20 Thorium & $2,2.5,3$ & $4.5^{\mathrm{a}}$ & 4.5 \\
\hline 2U20Th & $2 \mathrm{U} \& 20 \mathrm{Th}$ & $1,5,7,9,9.5,10$ & 11 & 10.5 \\
\hline
\end{tabular}

A 20 elemental weight percent Th glass was produced with the addition of 2 elemental weight percent uranium (2U20Th). This glass required 10.5 hours residence time with stirring every 1 to 2 hours to become homogeneous. XRD detected the thorium oxide/uranium oxide solid solution in decreasing amounts as the residence time increased. The maximum amount of thorium dissolved into the glass reached 20 elemental weight percent $(20 \mathrm{Th})$ at a slightly elevated temperature $\left(1500^{\circ} \mathrm{C}\right.$.) when uranium was not present. Aluminum borate was detected by XRD in the stirrings at $1475^{\circ} \mathrm{C}$. Consecutive stirrings saw no improvement in the melt. It was apparent that this composition (20Th) would not yield a homogeneous product at $1475^{\circ} \mathrm{C}$. Raising the temperature to $1500^{\circ} \mathrm{C}$ for 1.5 hours did yield a homogeneous product. It is possible that although uranium may decrease the rate of dissolution, it may also increase the maximum thorium loading in the glass at a given temperature (or effectively lower the melting point required for total dissolution). Future studies need to be performed to assess uranium's effect on glass production, actinide loading and residence time. 
Figure 1. Percent thorium dissolved into the LaBS glass with respect to time of a stirred, static and uranium spiked melts (15 wt \% Th).

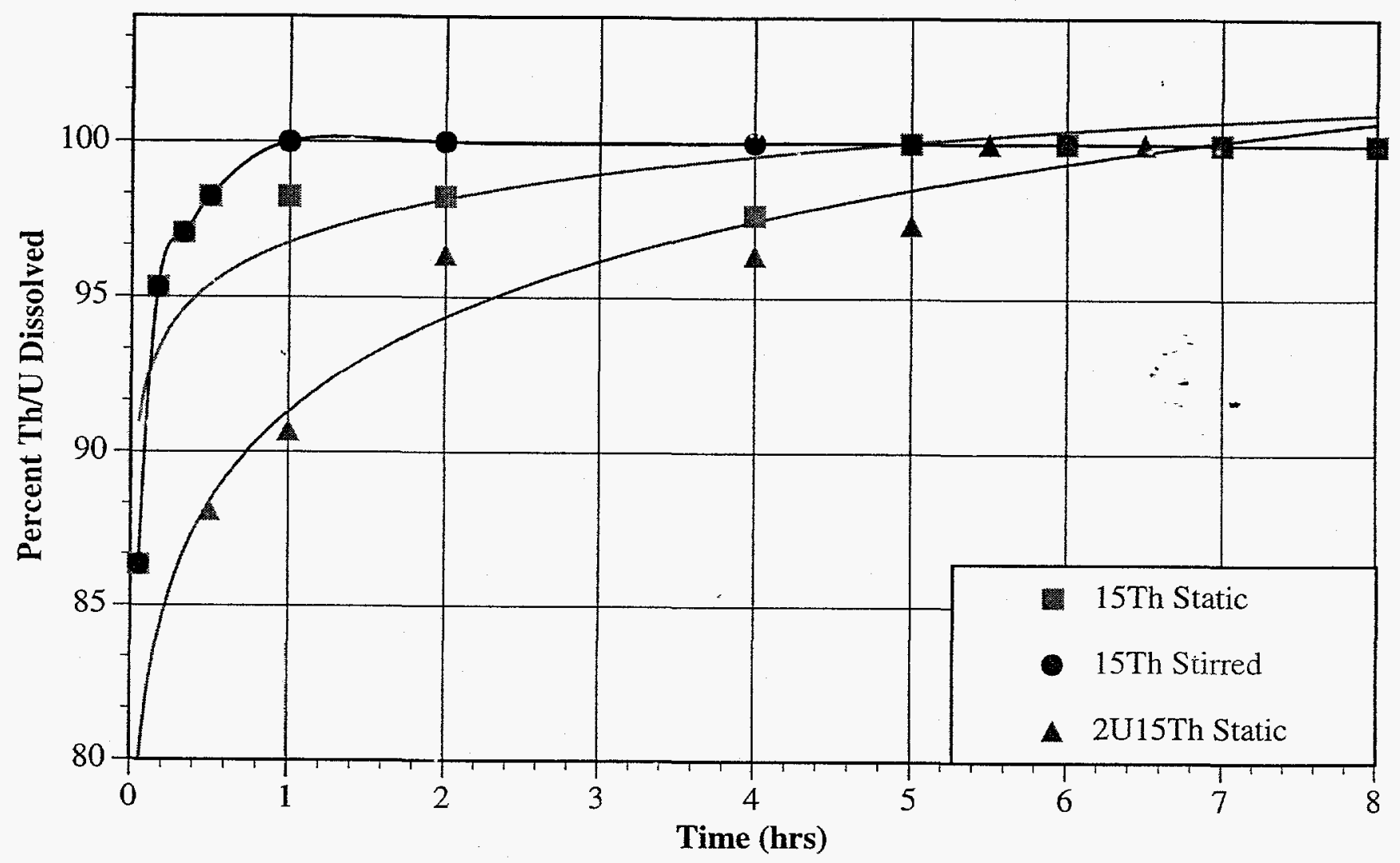

\section{Conclusions}

Using thorium as a plutonium surrogate, homogeneous glasses have been processed ranging from 15 to 20 elemental weight percent thorium with 0 to 5 elemental weight percent uranium. Homogeneous glasses have been processed at $1475^{\circ} \mathrm{C}$ with residence times ranging from 1 to 12 hours. High ramp rates successfully inhibited thorium silicate formation. Which, if formed, have previously showed to impede dissolution or increase the required residence times. Residence times of 5 to 8 hours were required for static melts to become homogeneous for glasses containing 15 elemental weight percent thorium. Thorium dissolution rates have been determined for glasses containing 15 elemental weight percent thorium with and without the addition of uranium. When compared to identicai glass compositions which were not stirred, stirred melts produced homogeneous products with as much as an 80 percent reduction in residence times. A 20 elemental weight percent thorium glass was produced at $1475^{\circ} \mathrm{C}$ by adding 2 elemental weight percent uranium. Without the addition of uranium, a melt temperature of $1500^{\circ} \mathrm{C}$ was required. 
Uranium addition to the predominately thorium loaded glasses appears to have two separate effects. First, dissolution kinetics are slowed. This is seen when comparing similar Th loadings with and without $U$ as well as similar total actinide loadings (Th plus $U$ being equal). Second, adding uranium appears to decrease the liquidus temperature of high Th loadings in the glass. This is evident in the 20Th melt, that was homogeneous only after increasing the melt temperature to $1500^{\circ} \mathrm{C}$ and the $2 \mathrm{U} 20 \mathrm{Th}$ melt that was homogenous at $1475^{\circ} \mathrm{C}$. 


\section{References}

1. Ramsey, W.G., et. al., "Vitrification of F-Area Americium/Curium: Feasibility Study and Preliminary Process Recommendation (U)," WSRC-TR-94-0211, Westinghouse Savannah River Company, Aiken, SC, (April, 1994).

2. Handbook of Chemistry and Physics, 63rd edition, CRC, (1982). 